\title{
Technology of e-Banking: Customer Perception and Satisfaction towards Public Sector Banks in Bhubaneswar City
}

\author{
${ }^{1}$ B.Rout, ${ }^{2}$ S.Samarpita, ${ }^{3}$ Prateek Lenka \\ ${ }^{1}$ Assistant Professor - Finance, Regional College of Management, Chakadola Vihar, Chandrasekharpur, \\ Bhubaneswar-751023, \\ ${ }^{2}$ Management Trainee, Bandhan Bank, \\ ${ }^{3}$ Management Trainee, Bandhan Bank,
}

\begin{abstract}
Present research is based on empirical evidences collected through the customers' survey regarding to the customers perception in internet banking services in public sectors bank in Bhubaneswar city. It is efforts to examine the relationship between the demographics and customers' satisfaction in internet banking, relationship between service quality and customers' satisfaction as well as satisfaction in internet banking service. The main aim of this study is to explore the effect of consumers' perception of risk and uncertainty on the rate of using internet banking as a new service and enhancing knowledge scope in this area. Regression analysis and multiple regression techniques have been employed for theory analysis. Statistical tests indicate that risk and uncertainty components have negative significant relationship with the rate of internet banking usage. Results show that highly educated, a person who are employees, businessmen and belongs to higher income group and younger group are using this service, however, remaining customers are not using this services. Results also show that overall satisfaction of employees, businessmen and professionals are higher in internet banking service.
\end{abstract}

Keywords: Service Quality, Perception; Customers' Satisfaction, Internet Banking Service.

\section{Introduction}

In its very basic form, e-banking can mean the provision of information about a bank and its services via a home page on the World Wide Web (WWW). More sophisticated e-banking services provide customer access to accounts, the ability to move their money between different accounts, and making payments or applying for loans via e-Channels. The term e-banking will be used in this book to describe the latter type of provision of services by an organization to its customers. Such customers may be either an individual or another business. Gone are the days when every banking transaction required a visit to the bank branch. Today, most of the transactions can be done from the home and customers need not visit the bank branch for anything. Technology is no longer an enabler, but a business driver. The growth of the internet, mobiles and communication technology has added a different dimension to banking. The information technology (IT) available today is being leveraged in customer acquisitions, driving automation and process efficiency, delivering ease and efficiency to customers.

Moving from a manual, scale-constrained environment to a global presence with automated systems and processes, it is difficult to envisage the adverse scenario; the sector was in the era before the reforms, when a simple deposit or withdrawal of cash would require a day. ATMs, mobile banking and online bill payments facilities to vendors and utility service providers have almost obviated the need for customers to visit a branch. Branches are also transforming from operating as transaction processing points into relationship management hubs. The change has been very productive for banks bringing in an increase in productivity and operational efficiency to be more competitive. Better risk management due to centralization of information and real time availability of critical data for decision making.

The world is changing at a staggering rate and technology is considered to be the key driver for these changes around us. An analysis of technology and its uses show that it has permeated in almost every aspect of our life. Many activities are handled electronically due to the acceptance of information technology at home as well as at workplace. Many of the IT initiatives of banks started in the late 1990s or early 2000 with an emphasis on the adoption of core banking solutions (CBS), automation of branches and centralization of operations in the CBS. Over the last decade, most of the banks completed the transformation to technologydriven organizations. Slowly but steadily, the Indian customer is moving towards the internet banking. The ATM and the Net transactions are becoming popular. But the customer is clear on one thing that he wants netbanking to be simple and the banking sector is matching its steps to the march of technology. E-banking or Online banking is a generic term for the delivery of banking services and products through the electronic channels such as the telephone, the internet, the cell phone etc. The concept and scope of e-banking is still 
evolving. It facilitates an effective payment and accounting system thereby enhancing the speed of delivery of banking services considerably.

A customer satisfaction is an ambiguous and abstract concept. Actual manifestation of the state of satisfaction will vary from person to person, product to product and service to service. The state of satisfaction depends on a number of factors which consolidate as psychological, economic and physical factors. The quality of service is one of the major determinants of the customer satisfaction, which can be enhanced by using ICT available to survive. The banks in India are using Information Technology (IT) not only to improve their own internal processes but also to increase facilities and services to their customers. Particularly, in the banking sector ICT is one of the most important tools, because it provides many suitable alternative banking channels to the customers. It brings connivance, customer centricity, enhance service quality and cost effectiveness in the banking services. Even now, customers are evaluating their banks based on availability of high-tech services. Therefore, implementation of ICT in the banking business continues to improve the banking service.

\section{Evolution Of E-Banking}

The term online banking was first started in $80^{\circ} \mathrm{s}$. The term online became popular in the late ' $80 \mathrm{~s}$ and referred to the use of a terminal, keyboard and TV (or monitor) to access the banking system using a phone line. "Home banking" can also refer to the use of a numeric keypad to send tones down a phone line with instructions to the bank. Online services started in New York in 1981 when four of the city's major banks (Citibank, Chase Manhattan, Chemical and Manufacturers Hanover) offered home banking services using the videotext system. Because of the commercial failure of videotext these banking services never became popular except in France where the use of videotext was subsidized by the telecom provider and the UK, where the Prestel system was used.

The UKs first home online banking services was set up by the Nottingham Building Society (NBS) in 1983 .The system used was based on the UK's Prestel system and used a computer, such as the BBC Micro, or keyboard (Tandata Td1400) connected to the telephone system and television set. The system (known as 'Home link') allowed on-line viewing of statements, bank transfers and bill payments. In order to make bank transfers and bill payments, a written instruction giving details of the intended recipient had to be sent to the NBS who set the details up on the Home link system. Typical recipients were gas, electricity and telephone companies and accounts with other banks. Details of payments to be made were input into the NBS system by the account holder via Prestel. A cheque was then sent by NBS to the payee and an advice giving details of the payment was sent to the account holder. BACS was later used to transfer the payment directly.

In India e-banking is of fairly recent origin. The traditional model for banking has been through branch banking. Only in the early 1990s there has been start of non-branch banking services. The good old manual systems on which Indian Banking depended upon for centuries seem to have no place today. The credit of launching internet banking in India goes to ICICI Bank. Citibank and HDFC Bank followed with internet banking services in 1999. Several initiatives have been taken by the Government of India as well as the Reserve Bank to facilitate the development of e-banking in India. The Government of India enacted the IT Act, 2000 with effect from October 17, 2000 which provided legal recognition to electronic transactions and other means of electronic commerce. The Reserve Bank is monitoring and reviewing the legal and other requirements of ebanking on a continuous basis to ensure that e-banking would develop on sound lines and e-banking related challenges would not pose a threat to financial stability. It issued guidelines on risks and control in computer and telecommunication system to all banks, advising them to evaluate the risks inherent in the systems and put in place adequate control mechanisms to address these risks. A high level Committee under chairmanship of Dr. K.C. Chakrabarty and members from IIT, IIM, IDRBT, Banks and the Reserve Bank prepared the "IT Vision Document- 2011-17 $7^{\mathrm{ec}}$, for the Reserve Bank and banks which provides an indicative road map for enhanced usage of IT in the banking sector. To cope with the pressure of growing competition, Indian commercial banks have adopted several initiatives and e-banking is one of them. The competition has been especially tough for the public sector banks, as the newly established private sector and foreign banks are leaders in the adoption of ebanking. State Bank of India (SBI) is the nation's largest and oldest bank. SBI has more 130 offices in nearly 35 other countries. SBI has been rolling out its own network of automated teller machines as well as developing anytime-anywhere banking services through internet and other technologies. The Bank is forging ahead with cutting edge technology and innovative new banking models. By the beginning of the 20th century, India's banking industry boasted a host of new arrivals and particularly foreign banks. The growth of the banking sector, and the development of indigenous banks, in turn creates a need for a larger "bankers" bank.

\section{Customer Satisfaction}

Customer satisfaction is a measure of how products and services supplied a company meet or surpass customer expectation. Customers perceive service in terms of quality, but how satisfied they are with the overall experience, is what defines their satisfaction. Kilter (2006:144) points out that whether the buyer is 
satisfied after purchase depends on the offer's performance in relation to the buyers expectations. Customer Satisfaction is when the outcome of the service matches the expectations of the service."There should be sufficient empowerment at the core and operating team level to enable them to champion the transformation across all stakeholders in the bank “

\section{Literature Review}

In the modern competitive world, service process performance is the most important to achieve competitive advantage. V. A. Zeithaml, A. Parasuraman and A. Malhotra(1985), stated that to deliver superior service quality, managers of companies with Web presences must first understand how customers perceive and evaluate online customer service. A. P. Gaudet suggested that technology satisfaction does drive overall customer satisfaction and that, in turn, overall customer satisfaction does drive loyalty. S. Byun revealed that consumers' value was a good predictor of behavioral intention to use the technology while the value was mainly determined by perceived benefit rather than perceived risk.

J. L. Heskett suggested that while customer satisfaction and loyalty provide a foundation for high levels of customer lifetime value, they support a range of customer behaviors with widely varying values, characterized by mere loyalty (repeat purchase), commitment (willingness to refer others to a product or service), apostle-like behavior (willingness to convince others to use a product or service), and ownership (willingness to recommend product or service improvements).

K. Szabó enlightend that by the 1990's the technological development becomes able to meet the users' requirements again. The biggest technological advancement since the personal computer and the primary technological force causing all corporations to rethink their business model, the internet is a system of millions of interconnected networks that spans to the earth (Wilson, 1996). A. T. Allred, H. L. Addams have analyzed service quality from the view of access, courtesy, communication, credibility, security, empathy, tangibles, basic service, fairness, fixing mistakes and guarantees and have concluded that majority of the respondents have stopped using a financial service provider because of poor service performance.

Kalakota and Whinstom (1997) state that "the message for marketers is clear: the purchasing climate and the products change quickly. In order to be competitive marketing executives must employ technology to develop low cost customer prospecting methods, establish close relationships with customers, and develop customer loyalty." The rapid growth of the Web creates a tremendous opportunity for new businesses, but also requires a new way of viewing the market place for community banker, "Experts estimates that consumer use of on-line banking services will increase over 20 -fold by the end of the century. Geography and the number of branches become irrelevant and community banks are able to offer the same level of service and convenience to customers as the largest banks. In the past, over $60 \%$ of existing bank customers have cited their bank selection to be based on convenience of location. For the customers of today, convenience of location includes the availability of 24-hour access via the Internet" (Wilson, 1996).

Davis (2003) proposed that costumer intention to use internet banking can be effected by customer attitude towards using internet banking. When customer have positive attitude they are more likely to adopt internet banking and vice versa.(Lichtenstein and Williamson,2006)

T. Rungting(2004) stated the expectations and perceived service quality strongly influence customers' emotions; emotions have a strong impact on the perception of service experience and customer satisfaction; and service experience mediates the effects of expectations, service quality, and emotions on customer satisfaction. Rajesh Kumar(2007) reveled in his study that, if skills can be upgraded their will be greater will to use internet banking by consumers. Inhibitory factors like trust, gender, education, culture, religion, security, price can have minimal effect on consumer mind set towards internet banking.

Vimi and Mohd (2008) undertook a study on the determinants of performance in the Indian retail banking industry based on perception of customer satisfaction and stated that customer satisfaction is linked with performance of the banks.

Bargal and Sharma(2008) analyzed the role of service marketing in banking sector. The identified important service factors in the banking sector are diversified services, flexible business transaction hours, accessibility of bank location, installation of web system, professional training to the employees, customers' complaint system and performance based appraisal system to enrich their services to their customers. Satisfaction of the customers is the key concept in marketing and it always assumed that the customer satisfaction is the crucial factor in determining the long run prosperity of the business.

Kumar Sarvana M (2009) stated that the service quality is categorized in five variables and, the difference between the perceived and desired level of service quaity is negative indicating that the perceived services of the sample banks fell short of the desired services.

The confirmation/disconfirmation paradigm views customer satisfaction judgments as the result of the consumer`s perception of the gap between their perceptions of performance and their prior expectations (Parasuraman et al., 1994); customer satisfaction in service industries has been approached differently by equity 
theory, attribution theory, the conformation and disconfirmation paradigm, and satisfaction as functional perception (Parker and Mathews, 2001). Increased research into customer satisfaction has been influenced dramatically by the variety of measurement scales used in customer satisfaction instruments tests (Devlin et al., 1991).

Tamas Jonas and Janos Kovesi (2010) stated that understanding the customers' voice is a key contributor to success of any organization that provides services. Customer sovereignty is the key concept in marketing and it always assumed that the customer satisfaction is the crucial factor in determining the long run prosperity of the business. K. Szabó highlighted that by the 1990's the technological development becomes able to meet the users' requirements again.

Andrew and Malinga(2011) recommended that more emphasis and efforts be laid on targeting indivisual clients. In addition, internrt banking service provide ought to look out for indicators of innovative ways of creating awareness about the service trough participation in trade organasiation as adoption of new technology of internet bankng.

Dr. Mohd Khalaf Ahmad \& Dr. Hasan Ali Al-Zu'bi(2011) stated that adoption of e-banking had a positive effect on Jordanian Commercial Bank customers' satisfaction, loyalty, and positive WOM.

\section{Objectives Of Study}

The main aim of the study is to assess the quality of facilities provided by State Bank of India to their customers and how the customers feel about the banking facilities (Technological products, E-banking, ATM \& other cards facilities).The objective of the study was:

- To evaluate the awareness of technological products among the customers of SBI.

- To measure the customer satisfaction in delivering the technological services provided by SBI.

- To study the most preferred technological service offered by SBI.

- To build up various solutions for drawbacks in the delivery mechanism of various technological services of the bank.

\section{Research Design}

A descriptive research method, which includes survey and fact finding enquires of different kinds, has been adopted

Population and Sample: The population defined for this study was limited to the customers of SBI Bank in Bhubaneswar city. In this study random sampling technique has been used and 100 customers were selected on random basis.

Database and Procedure of Analysis: Both primary and secondary data were used for the purpose of the study. One set of structured questionnaire was used to collect primary data for the study. Knowledgeable and potential respondents were consulted to make the questionnaire all inclusive. In a question, respondents were asked to indicate their level of satisfaction regarding various aspects of the implementation of technological products (such as performance, service quality, awareness, reliability, safety) of SBI Bank on a 5-point Likert type scale (1 for "Strongly disagree" to 5 for "Strongly agree"). For the outcomes of customer satisfaction dimensions, the research respondents were asked to indicate the degree of agreement or disagreement on the technological products that banks used as banking technique in order to achieve customer satisfaction. For the outcomes of satisfaction, the respondents were asked to indicate how important they believed of customer satisfaction. Multiple items were used to assess their measurement properties. Consistent with the literature, the scale items selected for the dependent variable were direct measures of customer satisfaction with influences received from implementation of technological products functionality as independent variables.

After developing the questionnaire, the customers availing services were identified from entire Bhubaneswar city. Respondents have been explained the objectives of the study and were requested to fill in the questionnaire on the spot. Besides this, many secondary sources have been used for supplementary purpose. Secondary sources include relevant web-based materials and prior research reports etc.

\section{Data Analysis}

Data have been analyzed by using statistical tools such as factor analysis and multiple regression analysis. Satisfaction level of the respondents was calculated using SPSS. By using the six factor analysis we found the main six factors which included all the twenty variables.By using these mean levels of satisfaction, information has been provided to use in analyzing the situation. Weighted Average Scores have also been calculated using SPSS and then ranking was done determining the aspect contributing the most towards the overall satisfaction of customers. 
Table 1: Demographic Profile of the Respondents

\begin{tabular}{|c|c|c|c|c|}
\hline Particulars & Frequency & Percent & $\begin{array}{l}\text { Valid } \\
\text { Percent }\end{array}$ & $\begin{array}{l}\text { Cumulative } \\
\text { Percent }\end{array}$ \\
\hline \multicolumn{5}{|l|}{ Gender } \\
\hline MALE & 75 & 75.0 & 75.0 & 75.0 \\
\hline FEMALE & 25 & 25.0 & 25.0 & 100.0 \\
\hline Total & 100 & 100.0 & 100.0 & \\
\hline \multicolumn{5}{|l|}{ Marital Status } \\
\hline SINGLE & 35 & 35.0 & 35.0 & 35.0 \\
\hline MARRIED & 65 & 65.0 & 65.0 & 100.0 \\
\hline Total & 100 & 100.0 & 100.0 & \\
\hline \multicolumn{5}{|l|}{ Age } \\
\hline$<25 \mathrm{YR}$ & 15 & 15.0 & 15.0 & 15.0 \\
\hline $25-35 \mathrm{YR}$ & 35 & 35.0 & 35.0 & 50.0 \\
\hline $36-45 \mathrm{YR}$ & 32 & 32.0 & 32.0 & 82.0 \\
\hline $46-55 \mathrm{YR}$ & 13 & 13.0 & 13.0 & 95.0 \\
\hline 55 YR \& ABV & 5 & 5.0 & 5.0 & 100.0 \\
\hline Total & 100 & 100.0 & 100.0 & \\
\hline \multicolumn{5}{|l|}{ Occupation } \\
\hline SERVICE & 84 & 84.0 & 84.0 & 84.0 \\
\hline BUSINESS & 6 & 6.0 & 6.0 & 90.0 \\
\hline STUDENT & 6 & 6.0 & 6.0 & 96.0 \\
\hline OTHERS & 4 & 4.0 & 4.0 & 100.0 \\
\hline Total & 100 & 100.0 & 100.0 & \\
\hline \multicolumn{5}{|l|}{ Annual Income } \\
\hline$<1 \mathrm{LAC}$ & 14 & 14.0 & 14.7 & 14.7 \\
\hline $1 \mathrm{~L}-5 \mathrm{~L}$ & 49 & 49.0 & 51.6 & 66.3 \\
\hline $5 \mathrm{~L}-10 \mathrm{~L}$ & 22 & 22.0 & 23.2 & 89.5 \\
\hline $10 \mathrm{~L} \& \mathrm{ABV}$ & 10 & 10.0 & 10.5 & 100.0 \\
\hline Total & 95 & 95.0 & 100.0 & \\
\hline \multirow[t]{2}{*}{ Missing } & 5 & 5.0 & & \\
\hline & 100 & 100.0 & & \\
\hline \multicolumn{5}{|c|}{ Year of Account with SBI } \\
\hline$<2 \mathrm{YR}$ & 13 & 13.0 & 13.0 & 13.0 \\
\hline $2-5 \mathrm{YR}$ & 34 & 34.0 & 34.0 & 47.0 \\
\hline $5-10 \mathrm{YR}$ & 33 & 33.0 & 33.0 & 80.0 \\
\hline $10 \mathrm{YR} \& \mathrm{ABV}$ & 20 & 20.0 & 20.0 & 100.0 \\
\hline Total & 100 & 100.0 & 100.0 & \\
\hline
\end{tabular}

There were two main reasons for analyzing the demographic features of the respondents of the research. First a clear profile of banking service users and second to analyze customer satisfaction issue based on demographic characteristics. This data is also used for further analysis and testing the hypothesis. Demographic profile includes gender, age, occupation, income level. Table 1 indicates the descriptive analysis for demographic information. Out of 100 respondents $75 \%$ of the respondents were male and $25 \%$ were female. In term of age group $15 \%$ were below 25 years, $35 \%$ were between 25 years to 35 years, $32 \%$ were between 36years to 45 years, $13 \%$ were between 46 to 55 years, and 5\% were above 55 years. There were $84 \%$ salaried persons doing service, $6 \%$ of business man/ woman, $6 \%$ students, and $4 \%$ having others as their occupation. Income profile of the respondents shows that there were $15 \%$ of the respondents having income below Rs. 1 lac, $52 \%$ having income between $1 \mathrm{lac}$ to $5 \mathrm{lac}, 23 \%$ of the respondents having income between 5 lac to 10 lac and $10 \%$ having income above 10 lac.

Table 2: Descriptive Statistics

\begin{tabular}{|l|l|l|l|l|l|}
\hline \multirow{2}{*}{ Variables } & $\mathbf{N}$ & Mean & Std. Deviation & \multicolumn{2}{l|}{ Skewness } \\
\cline { 2 - 6 } & Statistic & Statistic & Statistic & Statistic & Std. Error \\
\hline Satisfaction & 100 & 4.40 & .651 & -1.074 & .241 \\
\hline easy to use & 100 & 3.89 & .909 & -.932 & .241 \\
\hline employees responsive & 100 & 3.77 & 1.014 & -.649 & .241 \\
\hline variety of products & 100 & 3.92 & .837 & -.585 & .241 \\
\hline service charge & 100 & 3.89 & .909 & -.932 & .241 \\
\hline Technology & 100 & 3.66 & .924 & -.523 & .241 \\
\hline transaction time & 89 & 3.09 & 1.104 & .078 & .255 \\
\hline successful trans & 98 & 4.16 & .893 & -1.039 & .244 \\
\hline provides complete info & 100 & 3.67 & 1.074 & -.303 & .241 \\
\hline ATM's functional & 100 & 3.18 & 1.175 & .023 & .241 \\
\hline expanded network & 100 & 4.22 & .883 & -1.528 & .241 \\
\hline sends messages & 89 & 3.92 & 1.058 & -.783 & .255 \\
\hline sends info & 100 & 3.12 & 1.148 & -.035 & .241 \\
\hline
\end{tabular}




\begin{tabular}{|l|l|l|l|l|l|}
\hline intimation of products & 100 & 3.04 & 1.014 & .037 & .241 \\
\hline interest taken care & 100 & 3.79 & .988 & -.462 & .241 \\
\hline personal attention & 100 & 3.57 & 1.103 & -.688 & .241 \\
\hline Safety & 100 & 4.40 & .586 & -.369 & .241 \\
\hline employees behavior & 100 & 3.69 & .861 & -.319 & .241 \\
\hline Awareness & 100 & 2.79 & 1.166 & .382 & .241 \\
\hline Loyalty & 100 & 3.60 & 1.044 & -.380 & .241 \\
\hline
\end{tabular}

\section{Validity And Reliablity Tests}

Total Variance Explained

\begin{tabular}{|l|l|l|}
\hline \multicolumn{2}{|l|}{ KMO and Bartlett's Test } & .724 \\
\hline Kaiser-Meyer-Olkin Measure of Sampling Adequacy. & 469.721 \\
\hline \multirow{3}{*}{ Bartlett's Test of Sphericity } & Approx. Chi-Square & 190 \\
\cline { 2 - 3 } & Df & .000 \\
\cline { 2 - 3 } & Sig. & \\
\hline
\end{tabular}

KMO and Bartlett's Test is the strength of the relationship among variables large enough. Large values for the KMO measure indicate that a factor analysis of the variables is a good idea. Another indicator of the strength of the relationship among variables is Bartlett's test of sphericity. Bartlett's test of sphericity is used to test the null hypothesis that the variables in the population correlation matrix are uncorrelated. The observed significance level is .0000 . It is small enough to reject the hypothesis. The above table indicates that, in the present test the Kaiser-Meyer-Olkin (KMO) measure was 0.724 . Bartlett's sphericity test also found highly significant; Chi-Square $=469.721$, df $=190$ with a significance of 0.000 it provide support for validity of the factor analysis of the data set and indicates that, factor analysis is appropriate.

Table 3: Factor Analysis 
Technology of e-Banking: Customer Perception and Satisfaction towards Public Sector Banks in

\begin{tabular}{|c|c|c|c|c|c|c|c|c|c|}
\hline \multirow[t]{2}{*}{ Component } & \multicolumn{3}{|c|}{ Initial Eigen values } & \multicolumn{3}{|c|}{$\begin{array}{c}\text { Extraction Sums of Squared } \\
\text { Loadings }\end{array}$} & \multicolumn{3}{|c|}{$\begin{array}{c}\text { Rotation Sums of Squared } \\
\text { Loadings }\end{array}$} \\
\hline & Total & \begin{tabular}{c|}
$\%$ of \\
Variance \\
\end{tabular} & \begin{tabular}{|c|} 
Cumulafive \\
$\%$
\end{tabular} & Total & \begin{tabular}{|c|}
$\%$ of \\
Variance \\
\end{tabular} & \begin{tabular}{|c|} 
Cumulafive \\
$\%$
\end{tabular} & Total & \begin{tabular}{|c|}
$\%$ of \\
Variance \\
\end{tabular} & \begin{tabular}{|c|} 
Cumulafive \\
$\%$ \\
\end{tabular} \\
\hline $\begin{array}{l}\text { Service } \\
\text { quality }\end{array}$ & 5.129 & 25.647 & 25.647 & 5.129 & 25.647 & 25.647 & 2.514 & 12.572 & 12.572 \\
\hline Easy to use & 2.015 & 10.073 & 35.720 & 2.015 & 10.073 & 35.720 & 2.243 & 11.216 & 23.788 \\
\hline $\begin{array}{l}\text { employees } \\
\text { responsive }\end{array}$ & 1.522 & 7.612 & 43.332 & 1.522 & 7.612 & 43.332 & 2.199 & 10.995 & 34.783 \\
\hline $\begin{array}{l}\text { Variety of } \\
\text { products }\end{array}$ & 1.327 & 6.634 & 49.966 & $\mid 1.327$ & 6.634 & 49.966 & 2.053 & 10.263 & 45.046 \\
\hline $\begin{array}{l}\text { Service } \\
\text { charge }\end{array}$ & 1.180 & 5.898 & 55.864 & 1.180 & 5.898 & 55.864 & 1.683 & 8.417 & 53.463 \\
\hline Technology & $\mid 1.037$ & 5.187 & 61.051 & 1.037 & 5.187 & 61.051 & 1.518 & 7.588 & 61.051 \\
\hline $\begin{array}{l}\text { Transaction } \\
\text { time }\end{array}$ & .954 & 4.769 & 65.820 & & & & & & \\
\hline $\begin{array}{l}\text { Successful } \\
\text { transaction }\end{array}$ & .894 & 4.472 & 70.292 & & & & & & \\
\hline $\begin{array}{l}\text { complete } \\
\text { information }\end{array}$ & .850 & 4.249 & 74.540 & & & & & & \\
\hline $\begin{array}{l}\text { Atm's } \\
\text { functionsl }\end{array}$ & .725 & 3.626 & 78.166 & & & & & & \\
\hline $\begin{array}{l}\text { Expanded } \\
\text { network }\end{array}$ & .693 & 3.464 & 81.630 & & & & & & \\
\hline $\begin{array}{l}\text { Sends } \\
\text { messages }\end{array}$ & .660 & 3.298 & 84.928 & & & & & & \\
\hline $\begin{array}{l}\text { Sends info } \\
\text { Intimation of }\end{array}$ & .590 & 2.949 & 87.877 & & & & & & \\
\hline products & .524 & 2.618 & 90.495 & & & & & & \\
\hline $\begin{array}{l}\text { Interest } \\
\text { taken care }\end{array}$ & .458 & 2.290 & 92.786 & & & & & & \\
\hline $\begin{array}{l}\text { Personal } \\
\text { attention }\end{array}$ & .372 & 1.862 & 94.647 & & & & & & \\
\hline Safety & .332 & 1.659 & 96.306 & & & & & & \\
\hline $\begin{array}{l}\text { Employee } \\
\text { behavior }\end{array}$ & .296 & 1.481 & 97.787 & & & & & & \\
\hline Awgreness & .246 & 1.231 & 99.018 & & & & & & \\
\hline Loyalty & .196 & .982 & 100.000 & & & & & & \\
\hline
\end{tabular}

Table 4: Factor Analysis (Rotated Component Matrix)

\begin{tabular}{|c|c|c|c|c|c|c|}
\hline \multirow[t]{2}{*}{ Variables } & \multicolumn{6}{|c|}{ Component } \\
\hline & 1 & 2 & 3 & 4 & 5 & 6 \\
\hline Service quality & -.033 & -.022 & .718 & .143 & .038 & .315 \\
\hline easy to use & .250 & .337 & .072 & .480 & -.018 & -.043 \\
\hline employees responsive & .574 & -.053 & .226 & .159 & .127 & .463 \\
\hline variety of products & .001 & -.069 & .267 & .265 & .664 & .024 \\
\hline service charge & .465 & -.036 & .242 & .442 & .079 & .288 \\
\hline Technology & .309 & .227 & -.045 & -.163 & .745 & .079 \\
\hline transaction time & -.047 & .063 & .055 & -.108 & -.008 & .762 \\
\hline successful transaction & .061 & .006 & .457 & .410 & .437 & -.135 \\
\hline provides complete info & .553 & .199 & .432 & $\begin{array}{l}-.001 \\
\end{array}$ & .385 & -.096 \\
\hline atm's functional & .531 & .405 & .174 & .112 & -.418 & -.119 \\
\hline expanded network & .670 & -.065 & .086 & .181 & .054 & -.158 \\
\hline sends messages & .199 & .089 & .777 & .041 & .024 & -.081 \\
\hline sends info & .204 & .440 & .399 & -.237 & .200 & .005 \\
\hline intimation of products & .201 & .536 & -.049 & .229 & .081 & .424 \\
\hline interest taken care & .214 & .056 & .499 & .454 & .230 & 237 \\
\hline personal attention & .377 & .034 & .199 & .469 & .049 & .369 \\
\hline Safety & .133 & -.006 & .028 & .791 & .026 & -.085 \\
\hline employees behavior & .647 & .222 & -.051 & .203 & .185 & .240 \\
\hline Awareness & .090 & .836 & .022 & .208 & .089 & -.089 \\
\hline Loyalty & -.117 & .784 & .050 & -.115 & $\begin{array}{l}-.041 \\
\end{array}$ & .120 \\
\hline
\end{tabular}


The above table reveals that, the Eigen values associated with each linear component before extraction and after extraction. The Eigen values associated with each factor represent the variance explained by the particular linear component (Khan, 2006). First part of the table labeled as "Initial Eigen values" indicates that, first factor accounting $25.647 \%$ of variance in this model. Second part of the table labeled as "Extraction Sums of Squared Loadings" indicating same variance. However, third part labeled as "Rotation Sums of Squared Loadings" indicating that first factor accounting $12.572 \%$ of variance. It is pretty good figure because total variance is $61.051 \%$. It means, we lost only $38 \%$ approx. of the information content in our study. Rotation has the effect of optimizing the factor structure and one consequence for these data is that the relative importance of the three factors were equalized (Field, 2005). Rotation serves to make the output more understandable and is usually necessary to facilitate the interpretation of factors, therefore we have performed rotted matrix (Shapiro, 2002). The rotated component matrix (regression scores) table indicate factor loading. This is a matrix of the factor loading for each variable onto each factor.

Table 5: Regression Coefficients

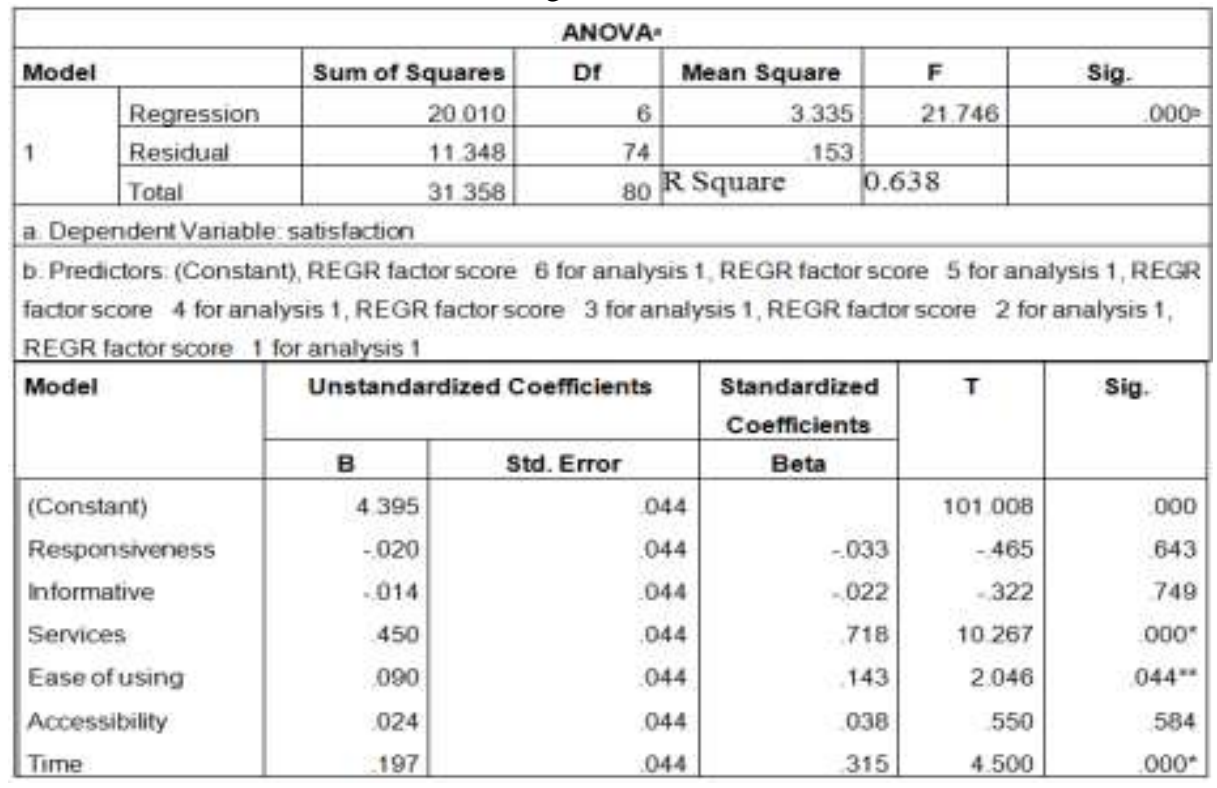

*Significant at 1 per cent level

**Significant at 5 per cent level

Factor 1: Responsiveness consists of six variables such as

- The employees of the bank are very responsive.

- The service charges of the bank is reasonable

- The bank provides complete information.

- The ATM's are always functional.

- The bank has expanded network.

- The employee's behavior inspires confidence in the customers.

Whose values are $0.574,0.465,0.553,0.531,0.670$, and 0.647 respectively.

Factor 2: Informative consists of four variables namely:

- The bank sends various information's frequently.

- There is regular intimation about new products.

- The customer is aware of all the products that SBI offers.

- The customer never switched his brand or the product that he used. Whose values are $0.440,0.536,0.836$, and 0.784 respectively.

Factor 3: Services consists of four variables namely:

- The customer is happy with the service quality of the bank.

- All the transactions are successful in the first time.

- The bank sends messages regularly.

- The bank has always the customer's interest at heart.

Whose values are $0.718,0.457,0.777$, and 0.499 respectively. 
Factor 4: Ease for using consists of three variables namely:

- The technological products of SBI are easy to use.

- The employees of the bank give personal attention to the customers

- The customers feel safe in the transactions with the bank.

Whose values are $0.480,0.469$, and 0.791 respectively.

Factor 5: Accessibility consists of two variables namely:

- The bank offers variety of products to suit customers' needs.

- The bank is having excellent and modern looking technology.

Whose values are 0.664 and 0.745 .

Factor 6: Time consists of only a single variable namely:

The customers do not have to wait very long for availing bank services online.

Whose value is 0.762 .

\section{Findings}

The above analysis indicated the following conclusion as:-

As per our analysis, following conclusions have been drawn:

1. The $\mathrm{R}$ square value of multiple regressions was coming 0.638 which indicate that all the six factor determines the core banking satisfaction of SBI by $63.8 \%$.

2. Also in ANNOVA table the significant value of $\mathrm{f}$ statistics is significant i.e .000 which is significant at $1 \%$ level. This means there is a validation exists in the model between dependent variables (satisfaction of core banking) and the six constructive independent variables which was derived through factor analysis.

3. We have applied " $t$ " statistics to measure the significant factors. The significant value of " $t$ " statistics in the Regression coefficient table shows that the factor 3, 4 and 6 namely services, ease of using and time are coming significant. The factor 3 and 6 are significant at $1 \%$ level and factor 4 is significant at 5\% level.

4. Males transact business with banks more than that of females. This is an indication that males have banking culture than females.

5. Inference from the research shows that $95 \%$ of the bank customers are satisfied with the products and services of the bank.

6. From the analysis we found that ATM, fund transfers are the most preferred product of SBI. However the customers were completely unaware of certain products like ASBA (Application supported by blocked amount), POS terminal. Despite of using such products they were not able to recognize these services by name.

7. The research found out that $32 \%$ of the customers are not informed ahead of time before a new product is introduced. However $34 \%$ of the sample was neutral about it.

8. The hypothesis also confirmed statistically at a level of significance of 0.05 that, customers are satisfied with the services of banks with modern technology.

9. Almost $33 \%$ of the samples were hard core loyal customers of SBI having their account with SBI between 5-10 years.

10. $95 \%$ of the samples felt safe while transacting with SBI. This shows that customers' satisfaction is high.

About $61.051 \%$ of the total variance in the 20 variables is attributable to the first six components. Also we can judge how well the six-component model describes the original variables, by examine the above table and concluded that Component 1 explains a variance of 2.514 , which is $12.572 \%$ of total variance of 20 ; Component 2 explains a variance of 2.243, which is $11.216 \%$ of total variance. Similarly, same kind of conclusion can be drawn for other components. The amount of variance accounted for by the six components is 12.21 , which about $61.05 \%$ of the total variance in the 20 variables is attributable to the first six components $(12.21 / \mathbf{2 0}=.6105)$, and remaining 14 components together accounts for $38.95 \%$ of the total variance.

\section{Suggestions}

- $\quad$ SBI may increase the satisfactory level by simplifying the process and the procedure in order to make easily understandable by all people, to meet the competition from other banks,

- The people less than 40 years of age are more aware about e-banking. As for elders the banks can create the awareness and clear their doubt and fear about the e-banking process, so that they may get more depositors/customers to make their transaction through e-banking.

- The banks to get more number of customer to using e-banking, may advertise about the schemes and proper usage of the technology. 
- Banks can introduce On-line Banking Service (OBS) in two modes such as Beginner and Expert Mode .The Beginner Mode should consist of the Help option which can guide the users who are not much familiar with OBS to proceed for further facilities in a correct manner. Likely, the other mode comprise of the Expert Mode in which the person who is friendly with OBS can directly operate or go through the transaction options to save his/her time. It increases customer's friendliness, awareness and also increases quality of OBS.

- Strong anti-hacking system has to be tailored to not only strengthen online user's authentication for the vast Online Banking system but also to defend the theft of customer's privacy from internet hackers.

- Banks should pay attention to reach out their female customers who-in a majority of cases-would have less experience and willingness to avail OBS by facilitating direct shopping through Online Banking with some special discounts over particular range. So that transaction frequency as well as amount that has been

- Transact through Online Banking will increase and results to the increment of bank's productivity.

- Banks must also ensure that the various ATM in the city should be functional and have enough cash balance so that the customers may transact without any hassles.

- Banks may create awareness among the customers about new products and services by sending e-mails, letters, or messages.

[1]. Allred A T, Addams H L, Service quality at banks and credit unions: what do their customers say?, Management Service Quality 10 (2000), no. 1, 52-60

[2]. Bargal and Sharma (2008), Role of service marketing in Banking Sector, The Icfai Journnal of Service marketing vol-VI, no. 1,62.

[3]. Andrew Musiime and Malinga Ramadhan(2011), "Internet banking, consumer adoption and consumer satisfraction", African jurnal of marketing management, Vol 3(10), October 2011, pp261-269

[4]. Customers' preference on Internet Banking, survey (Retrieved from http://www.itwire.com/content/view/4570/53 on 20 March 2009)

[5]. Dr. Ala`Eddin Mohd Khalaf Ahm'ad \& Hasan Ali Al-Zu’bi (2011), "E-banking Functionality and Outcomes of Customer Satisfaction: An Empirical Investigation", International journal of marketing studies, vol.3, No.1; Feb 2011.

[6]. Gaudet A P (2004), "Customer relationship marketing and effects of demographics and technology on customer satisfaction and loyalty in financial services", Old Dominion University, United States, Virginia, 2004.

[7]. Heskett J L (2002), "Beyond customer loyalty, Managing Service Quality MCB UP ltd 12(2002), no.6-355-57.

[8]. Kumar Sarvana M. (2009), "An Analysis on Customer,s satisfaction on e-banking and services: A case study of selected commercial banks in Coimbatore city, in Journal oc contemporary research in management, jan-mar-2009, pp-11-21.

[9]. Kaur Kamalpreet \& Kaur Mandeep (2011), Adoption and Diffusion of Electronic Banking by Customers: Critical Analysis of Empirical Evidences, International Journal of Financial Management, Volume 1 Issue 1.

[10]. K. Szabó (1990), "Customer authentication, as a matter of risk in financial services", Periodical Polytechnic Social and management Science 11 (2003) 13-26.

[11]. Lichtenstein S, Williamson K(2006), “ Understanding consumer adoption of internet banking: An interpretive study in Australian banking Context.” Journal of electronic commerce research, Vol 7, No. 2, 2006.

[12]. Parasuraman, A. Zeithaml Valarie A. and Malhotra Arvind (2005) E-S-QUAL: A Multiple-Item Scale for Assessing Electronic Service Quality, Journal of Service Research, Volume 7, No. X, (Islam, Biswas, \& Kumar, 2007)Month 2005 1-21

[13]. Parasuraman, V. Zeithaml and L. Berry, "A Conceptual Model of Service Quality and its Implications for Future Research", Journal of Marketing, Vol.49 (Fall), 1985, Pp.40-50.

[14]. Parasuraman, V. Zeithaml and L. Berry, 'SERVQUAL: A Multiple-item for Measuring Consumer Perception of Service Quality', Journal of Retailing, Vol. 64 (Spring), 1988) Pp.12-40.

[15]. Rajesh Kumar srivastava(2007), “Customer's perception on uses of internet anking, innovative marketing” Vol 3, Issue 4, pp 67.

[16]. S. Byun (2007), "The value of technology in service encounters: Exploring consumer perception of biometric access at automatic teller machines", Purdue University, United States, Nov 2007.

[17]. Tamas Jonas and Janos Kovesi (2010) "Reliability based customer satisfaction evaluation", Periodical Polytechnic Social and management Science 18/1 (2010) 3-9

[18]. T. Rungting (2004), "service quality and expectation: The critical impact of emotions and services on customer satisfaction, The University of north Carolina at Chapel hill, United hill, United States - North Carolina, 2004.

[19]. Vimi J, Mohd K K(2008), "Determinants of performance in retail banking : perspectives of customer satisfaction and relationship marketing, Singapore management Review, December 2008.

[20]. V. A. Zeithaml, A. Parasuraman and A. Malhotran (2005), “A Multiple - Item Scale for Assessing Electronic Service Quality, Journal of Service Research, Vol 7 no. $3213-233$. 